\title{
Effect of Financial Hedging on Capital Investments of Non-Financial Firms
}

\author{
Vasantha Rao Chigurupati*, T.T. Allain Hall
}

Assistant Professor of Finance Department of Accounting, Finance and Economics Room \#240 Southern Universities and A\&M College Baton Rouge, LA 70813 USA

DOI: $10.36347 /$ sjebm.2020.v07i10.002

| Received: 08.10.2019 | Accepted: 15.10.2019 | Published: 30.10 .2020

*Corresponding author: Vasantha Rao Chigurupati

Abstract

Original Research Article

This paper examines, in an empirical setting, the effect of financial hedging on investment decisions by non-financial firms. Using the total notional values of currency, interest rate and commodity derivatives as a measure of financial hedging by non-financial S\&P 500 firms for a period of 1996-2000, we find that financial hedging reduces the sensitivity of investments to cash flow for the sample firms. This result holds even after controlling for several other variables including debt ratio, Tobin's Q, and size. We find that hedging increases debt capacity and also hedging reduces the cash flow variability thus reducing the probability of financial distress. Consistent with past studies, We also find that investment is significantly negatively correlated with leverage and significantly positively correlated to internal cash flow and firm size.

Keywords: Hedging, Investment, Debt Capacity and Financial Distress.

Copyright $(\mathcal{2 0 2 0}$ The Author(s): This is an open-access article distributed under the terms of the Creative Commons Attribution 4.0 International License (CC BY-NC 4.0) which permits unrestricted use, distribution, and reproduction in any medium for non-commercial use provided the original author and source are credited.

\section{INTRODUCTION}

This paper examines empirically the effect of financial hedging on investment expenditures by firms. Before addressing this question, it is important to briefly review the question of why firm's hedge and the resulting benefits of hedging to firms that engage in risk management activities. In the classical Modigliani and Miller [1] world of perfect capital markets, a firm's hedging activities are irrelevant in determining firm value since individual investors in the company's common stock can buy and sell derivative contracts using their personal accounts. However, in actual financial markets, firms face a variety of market imperfections, such as: information asymmetry, agency costs, financial distress and bankruptcy costs, taxes, transaction costs, costly external financing and incomplete contracting. Further, in perfect capital markets, hedging systematic or non-systematic risks cannot increase firm value if the cost of bearing such risks is same within the firm or outside the firm by capital markets. Also, in general, corporations are in a much better position to manage certain macroeconomic factor risks such as interest rate, currency exchange rate, and commodity price risks than the shareholders who may be well diversified to firm specific risks. There are several well explained motivations for firms to undertake hedging in the first place and the associated benefits. These are reviewed, respectively, briefly in sections A and B below:

\section{Motivations for Hedging \\ Managerial risk aversion}

Corporate volatility can be costly for the managers if they have concave utility functions i.e. they are risk-averse and if some of their compensation is related to the volatility of corporate income or cash flows. According to Stulz [2], if managers cannot effectively hedge corporate volatility in their personal accounts or if it is cheaper for the firms to hedge than it is for managers, then managerial welfare may be improved by corporate hedging. However, the empirical evidence on this is mixed as Haushalter [3] and Geczy et al. [4] find no evidence that either managerial risk aversion or shareholdings affect corporate hedging.

\section{Asymmetric information}

Asymmetric information in debt markets can cause distortions similar to those for new share issues. Asymmetric information may increase the cost of new debt, or even result in credit rationing. In the extreme, a "financial collapse" may occur, in which some or all classes of asymmetric-information borrowers are denied loans. DeMarzo and Duffie [5] argue that equityholders can benefit from hedging when managers have private 
information about an unobservable risk that affects the firm's payoffs. Equityholders support hedging because they can make better portfolio optimization decisions. DeMarzo and Duffie's model suggests that equity holders of firms with greater informational asymmetry will derive greater benefits if the firm hedges. As Bessembinder [6] argues, if a firm can credibly commit to a hedging policy at the time of a financing decision, the value of debt becomes less sensitive to incremental investment decisions and thus mitigates the underinvestment problem. Hubbard [7] investigates the investment decisions of firms in the presence of capital market imperfections.

Breeden and Viswanathan [8] present an asymmetric information model of hedging where hedging is undertaken by higher ability managers who wish to "lock-in" the higher profits that result from their higher ability. Thus, hedging is an attempt to improve the informativeness of the learning process. This model assumes that the labor market revises its opinion about the ability of managers based on their firm's performance. This can lead some managers to undertake hedging in an attempt to influence the labor market's perception about their managerial ability.

\section{Financial Distress}

According to Smith and Stulz [9], financial distress costs provide a possible explanation of why firms hedge. If financial distress is costly, firms are better off with hedging activities because they reduce its probability. Assuming a fixed investment policy, they argue that hedging can decrease the present value of financial distress costs even if hedging is costly. Hedging increases shareholder's wealth because it decreases the expected value of direct bankruptcy costs and the loss of debt tax shield. However, as argued in Purnanandam [10] the existing empirical studies find mixed evidence in support of the distress-cost based theories of hedging. For example Graham and Rogers [11], Haushalter [3] find a positive relation between hedging and leverage (a proxy for distress) evidence where as Mian [12], Tuffano [13] do not find a positive relation between the two variables.

\section{Tax incentives}

Smith and Stulz [9] argue that if taxes are a convex function of earnings, then it is optimal for firms to hedge. Graham and Rogers [11] report that firms hedge to increase debt capacity and interest deductions. They also identify an important link between hedging and the capital structure decisions and argue that hedging-leverage causality can go both ways.

\section{Benefits of Hedging \\ Mitigates the underinvestment problem}

In the presence of risky debt in the firm's capital structure, equityholders may underinvest by giving up positive NPV investments because the project's benefits accrue to the existing debtholders and the existing debt load makes it too costly for the firm to borrow in external capital markets. This creates the underinvestment problem due to debt overhang as per Myers and Majluf [14]. Thus the firms borrowing capacity and the availability of cash are important determinants of its investment decisions. Froot et al. [15] predict that a well-designed risk management program should enable firms to optimally coordinate their financing and investment policies. The basic logic according to Froot et al. is as follows:

If a firm does not hedge, there will be some variability in cash flows generated by assets in place. This variability in internal cash flow should result either variability in the amount of money raised externally or variability in the amount of investment. However, in general, firms consider variability in investments as undesirable. In a perfectly elastic or frictionless capital market firms can easily accommodate the changes in internal cash flow, without affecting the level of capital investments, by appropriately altering the amount of capital raised externally. But, as mentioned earlier, in real financial markets firms do face various frictions such as financial distress and bankruptcy costs, taxes, costly external financing, incomplete contracting and asymmetric information. These frictions make the external funds costlier than the internal funds and also the marginal cost of funds goes up with the amount raised externally. Now, a shortfall in internal cash has to be met with either raising costly external financing or decreasing the investment or both. Thus variability in internal cash flows can disrupt the investment and financing plans in a way that is costly to the firm. To the extent hedging can reduce this variability in cash flows, it can reduce the underinvestment problem and add value to the firm.

If effective hedging reduces cash flow volatility, decreases the cost of distress, decreases a firm's expected tax liability, and increases debt capacity (i.e. enhances ability to raise funds from external capital markets), then the sensitivity of investment to internal cash flow should be less. There is considerable evidence that firms, at least partly, base their level of investment on the availability of cash flow. For US based firms, Fazzari, Hubbard, and Petersen [7] find that the changes in firms' yearly capital expenditures are highly positively correlated with the changes in the annual cash flows. Hoshi, Kashyap, and Scharfstein [15] find similar evidence for Japanese firms. Gay and Nam [16] report that firms' derivatives use is driven partly by the need to mitigate the underinvestment problems.

Anecdotal evidence, from the 1997 annual financial statement of Apache Corporation, a S\&P 500 firm, is mentioned below:

"The Company funds its exploration and development activities primarily through internally generated cash 
flows. Apache budgets capital expenditures based upon projected cash flows. The Company routinely adjusts its capital expenditures in response to changes in oil and natural gas prices and cash flow. The Company cannot accurately predict future product prices."

\section{Increases debt capacity}

Hedging can reduce the probability that a firm will find itself in a state where it is not able to meet its debt obligations. This reduction in the probability of financial distress and associated cost of distress increases the debt capacity as per Ross [17]. Leland [18] argues that if firms take on more debt in light of this increased debt capacity; the associated increase in interest deductions reduces tax liabilities and also reduce the "free cash flow problem" associated with agency related issues

\section{Increases firm value}

In general, risk management theory assumes that the deadweight cost caused by the capital market frictions decreases if a firm's cash flow volatility is reduced. Hence, hedging is supposed to increase firm value by decreasing cash flow volatility. Using a sample of airline companies, Carter et al. [19] conclude that hedging increases firm value by 12 to $16 \%$, which they attribute to reduced external financing costs. Graham and Rogers report that the tax benefits resulting from hedging add about $1.1 \%$ to firm value. Allayannis and Weston [20], using a sample of large US nonfinancial firms with foreign sales, conclude that hedging increases firm value by $3-8 \%$.

Froot et al. provide the theoretical basis for optimally coordinating the investment and risk management activities by corporations. However, there is little empirical literature on the direct effect of corporate hedging on a firm's ex-post investment decision. Hence, we investigate the effect of a firms' hedging practice on its investment (capital expenditure) decision by using a broad based hedging measure that includes interest rate, foreign exchange, and commodity price risks $\left[{ }^{1}\right]$.

This paper aims to contribute to the finance literature by integrating the cash flow - investment constraints literature and the risk management literature in an empirical setting. Using the total notional values of interest rate, and currency derivatives as a measure of financial hedging by non-financial S\&P 500 firms for a recent time period of 1996-2000, we find that financial hedging reduces the cash flow sensitivity of investment expenditures by firms. This result holds even after controlling for several other variables like debt ratio,

1 For the limited sample size used in this paper, we exclude the commodity hedging in the measurement of notional values of hedging. Risk management activities by firms may include other types of non-financial hedging activities such as operational hedges which are not reported in the financial statements and are difficult to observe.
Tobin's Q, size etc. This paper also examines the source(s) for this reduced sensitivity and provides direct evidence that the reduction in the variability of hedged cash-flow as a possible explanation of the reduced sensitivity of capital expenditures to internal cash-flow for the firms engaged in hedging. Another possible explanation provided in the paper is that hedging increases the unused debt capacity. This should reduce the sensitivity of capital expenditure to internal cashflow. However in light of the simultaneity issue between leverage and hedging as depicted in Graham and Rogers [11], and Lin and Smith[21] this evidence has to be treated with caution. Consistent with previous studies, we also find that investments are significantly negatively related with leverage and positively related to firm size and internal cash flow.

The rest of the paper is organized as follows. Section-I discusses the motivation and develops testable hypotheses. Section-II deals with data collection, variable measurement and the sample. Section-III covers empirical modeling and estimation. Section-IV reports the results and checks their robustness. Finally, Section-V concludes.

\section{Motivation and Hypothesis development}

Following the seminal papers of Froot et al.[15], and Fazzari et al.[22], there has been two distinct strands of literature- one on the cash flow constraints and investment [Kaplan and Zingales [23], Moyen [24]] and the other on hedging and firm value [Allayannis and Weston[25], Carter et al. [19] etc.]. Fazzari, Hubbard, and Petersen [22] find that positive relation between changes in yearly capital expenditures and changes in annual cash flows is stronger for firms facing financial constraints stemming from capital market imperfections $\left[{ }^{2}\right]$. Allayannis and Weston, and Carter et al. conclude that hedging increases firm value. Froot et al. predict that firm's hedge to mitigate the underinvestment problem and argue that a welldesigned risk management program should enable firms to optimally coordinate their financing and investment policies.

Though Froot et al. provide the theoretical basis for optimally coordinating the investment and risk management activities by corporations, there is little

2 Please note that FHP infer investment - cash flow sensitivity as a proxy for financial constraints. $\mathrm{KZ}$ take an exception to this and argue that investment-cash flow sensitivities are not useful measures of financial constraints. Also, the inherent problems in measuring Tobins' $Q$ and the inadequacy of $\mathrm{Q}$ for controlling the investment opportunities may be driving the positive relation between Inv-CF. There is considerable debate in literature on this and the evidence is mixed. Moyen [24] tries to reconcile the differences in literature and offers evidence that is consistent with both FHP and KZ. However, in this study, our objective is not to use Inv-CF sensitivity to identify the financial constraints but examine the effect of hedging on Inv-CF sensitivity as per theoretical prediction of FSS. 
empirical literature on the direct effect of corporate hedging on a firm's ex-post investment decision. This requires integrating the literature on financial constraints and investments, and on hedging in an empirical setting. Hence, we investigate the effect of firms hedging practice on its investment (capital expenditure) decision. One notable exception is the working paper by Allayannis and Mozumdar [26] (AM hereafter). While AM examine a similar issue they only look at currency hedging by firms.

However, as per the Wharton research survey of financial risk management by non-financial firms, Bodnar et al.[27] report that financial risk is classified broadly into interest rate, foreign currency, commodity, and equity risk. They also report that foreign-exchange risk is managed by $83 \%$ of derivative users, interest rate risk is managed by $76 \%$ of the firms using derivatives, commodity risk by $56 \%$ of the derivative users and equity risk by only $34 \%$ of the firms in their survey.

Also with the introduction of SFAS 119, which became effective starting the fiscal year 1995, the quality of data on corporate hedging available in annual reports(10Ks) has considerably improved. Hence we use the more recent data starting from 1996-2000.

Finally, AM measure hedging as a dummy variable. As per Gay and Nam [16] and Allayannis and Ofek [20], we use the notional values of the various financial hedges as a continuous measure of hedging. In a recent study, using precious metal mining firms, Chung [28] shows that a firm that employs intensive hedging activities through derivatives tends to experience both statistically and economically significant risk reductions on its future cash-flows as well as equity returns. In addition, he argues that financial analysts incorporate information about a firm's hedging strategy and finds that it is reflected in their earnings forecasts.

This paper aims to contribute to the finance literature by studying the effect of a broad based hedging policy that includes interest rate, foreign exchange, and commodity risks in the measurement of financial hedging on the capital expenditure by nonfinancial firms. Risk management activities by firms may include other types of non-financial hedging activities such as operational hedges which are not reported in the financial statements and are difficult to observe. Hence we focus only on the financial hedging of non-financial firms. Based on the above arguments, we propose the following testable hypotheses:

\section{H1: Investment expenditure will be positively related to the derivative hedging activity.}

This follows directly from the argument that hedging mitigates the underinvestment problem by increasing the debt capacity and reducing the probability of financial distress.
H2: Investment expenditure by firms that hedge is less sensitive to internal funds.

This follows from the argument that hedging reduces the capital market frictions and increases the debt capacity, reduces the weighted average cost of external capital, and decreases the probability of financial distress by reducing the cash flow variability.

\section{H3: Investment expenditure by firms that hedge would respond more strongly to the investment opportunities $(Q)$.}

If hedging lowers the cost of external capital, then the net present value of an investment increases. As financially constrained firms with higher growth opportunities suffer the most by financial distress costs, they should invest more to minimize the underinvestment problem.

\section{Data, Variable measurement, and Sample description}

We collected the panel data on a sample of firms in the S\&P 500 index, excluding financial firms, utilities and telecommunications, for the period of 1996-2000 from COMPUSTAT Annual database. We excluded financial firms as they use derivatives for trading purposes. I also excluded the highly regulated utility and telecom sectors from the sample. The complete list of S\&P 500 firms was provided by the index services of S\&P. We used Thomson financial database to obtain the historical annual financial statements (10-Ks). We manually identified the notional values of currency, interest rate, and commodity hedging by performing a string search using keywords like hedge, derivatives, swaps etc. on the 10-Ks. The notional amounts of derivatives do not represent actual amounts exchanged by the parties and, thus, are not an accurate measure of the exposure of the Company through its use of derivatives. To this extent the measure of hedging is noisy.

Considering the laborious nature of this data collection, we restricted data collection to a random sample of four firms within each industry category. In the final sample there are seven sectors, twenty eight firms with data collected over the five year period from 1996-2000. we chose this time period because Financial Accounting Standards Board (FASB) implemented Statement of Financial Accounting Standards (SFAS) No. 133, "Accounting for Derivative Instruments and Hedging Activities." in June 2000 and most firms adopted it by 2001. This statement requires that firms recognize all derivatives as either assets or liabilities and measure those instruments at fair market value and it no longer requires the disclosure of notional values. The problem with the fair value is that it only provides information on the amount the contract holder would receive or pay to liquidate the contract. Furthermore, many derivative contracts have a market value of zero at the time of origination. The actual list of firms in the 
sample is identified in the Appendix $\left[{ }^{3}\right]$. Please refer to the Appendix for more details on the accounting treatment of financial risk management activities by various firms as identified in their annual financial statements.

We now focus on the issue of measurement of cash flow. Since my objective is to check if financial hedging reduces the firm's internal cash flow volatility, and the sensitivity of investments to internal cash flow, it is important to measure the unhedged cash flow from operations. Following AM, we use Net Operating Profit Less Adjusted Tax (NOPLAT) plus Depreciation and Amortization (DA) minus change in Working Capital $(\Delta \mathrm{WC})$ i.e. [NOPLAT $+\mathrm{DA}-\Delta \mathrm{WC}$ ] as a measure of unhedged cash flow.

We use Tobin's Q as a proxy for the firm's growth opportunities. There are several ways to measure Q and most empirical studies measure the average $\mathrm{Q}$ whereas what one really needs to measure is a marginal Q. There is a considerable debate on whether $\mathrm{Q}$ as measured conventionally is indeed a good measure of growth opportunities. As per Harvey et al. [29], we use the ratio of market to book value of total assets as a measure of $\mathrm{Q}\left[{ }^{4}\right]$. Debt ratio is measured as the ratio of book value of long term debt to the book value of total assets. Firm size is measured as a natural logarithm of book value of total assets. Capital investments are measured as capital expenditure.

Table-I provides the descriptive statistics of the key explanatory variables. In the final sample, the maximum value of hedging variable $(\mathrm{H})$ scaled by capital stock $(\mathrm{K})$ i.e. $\mathrm{H} / \mathrm{K}$ is 9.7928 and the minimum value is 0.0167 . The median firm has a $\mathrm{H} / \mathrm{K}$ value of 0.5742 . Similarly investments scaled by capital stock i.e. $\mathrm{I} / \mathrm{K}$ has a range of 0.10 to 0.72 with an average value of 0.25 and a median value of 0.23 .

The pairwise correlations among the key variables are reported in Table-II. The scaled cash flow $(\mathrm{CF} / \mathrm{K})$ is significantly and highly positively correlated to the scaled capital investments $(\mathrm{I} / \mathrm{K})$ with a correlation coefficient of 0.278 . Similarly firm size measured as $\log$ (total assets) is highly significant and positively correlated to $\mathrm{I} / \mathrm{K}$ with a correlation coefficient of 0.406 . However, I/K is significantly negatively correlated to the lagged debt ratio and has a correlation coefficient of -0.24 . Finally, lag $(H / K)$ is positively correlated to $I / K$ with a correlation coefficient of 0.013 but it is not significant.

\footnotetext{
${ }^{3}$ Deleted for this submission and available upon request

${ }^{4}$ Recently, Adam and Goyal [30] examined various proxies for the investment opportunities and concluded that the market-to-book assets ratio has the highest information content with respect to investment opportunities.
}

\section{Empirical Model and Estimation}

We use the following model for estimation and hypotheses testing. Following FHP [22], this model is used quite often in the financial constraints and investment literature, [Kaplan and Zingales [23], Hubbard [7], and Moyen [24]]. However, the model below contains hedging i.e. the notional value of derivative contracts as a test variable in addition to several other control variables.

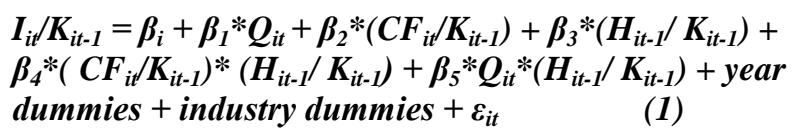

Here $\mathrm{K}$ is the capital stock at the beginning of period $\mathrm{t}$ and it is measured as net property, plant and equipment (PPE).

Based on this model, we predict that $\beta 3$ and $\beta 5$ are positive and $\beta 4$ is negative. We estimate this model using the Fixed Effects (FE)/Least Squares Dummy Variable (LSDV) technique. One can argue that hedging and investment are strategic decisions that are jointly determined in any given period. In order to mitigate the simultaneity bias between contemporaneous hedging and capital investment decision, we use one period lagged value of $\mathrm{H}\left[{ }^{5}\right]$. However, this may not be completely satisfactory if the error terms are autocorrelated. Hence, we exploit the panel structure of the data and reestimate equation 1 using the change in levels by first differencing the data $\left[{ }^{6}\right]$. This serves as a useful check against potential autocorrelation in the data. The change regression also control endogeneity in a better way as it removes firm specific unobservable effects such as managerial quality that could be correlated with hedging and investment at any given time. Alternatively, we can use either twostage least squares (2SLS) or instrumental variable (IV) estimation techniques. We use both heteroskedasticity and autocorrelation robust standard errors for inference because the usual OLS standard errors are downward biased and can lead to rejecting the null more often[ $\left.{ }^{7}\right]$.

\footnotetext{
${ }^{5}$ Wooldridge (2002) argues that in applied econometrics, endogeneity usually arises in three ways viz. omitted variables, measurement error, and simultaneity. He mentions that the distinctions among the three forms are not always sharp and an equation can in fact have more than one source of endogeneity. The use of lagged dependent variables in dynamic models could be yet another source of endogeneity!

${ }^{6}$ The Change regression results are not reported in the paper but available upon request.

${ }^{7}$ Petersen (2008) offers a comprehensive comparison of different approaches used in estimating standard errors in financial panel data sets.
} 


\section{RESULTS AND ROBUSTNESS CHECKS} Results

Based on the results reported in Table-III, the coefficient $\beta_{3}$ associated with hedging is positive as expected but it is not statistically significant. Hence, we reject the hypothesis $\mathrm{H} 1$ that hedging increases investment expenditures. The coefficient $\beta_{4}$ associated with hedging and cash flow interaction is equal to 0.027 and highly significant. This supports the hypothesis $\mathrm{H} 2$ that hedging reduces the sensitivity of investments expenditures to cash flow. The coefficient $\beta_{2}$ associated with cash flow is equal to 0.085 and highly significant. This replicates the earlier result of FHP [22] that investments expenditures are highly sensitive and directly proportional to cash flow. The coefficient $\beta_{5}$, associated with the interaction of $Q$ and hedging, is equal to 0.003 and statistically insignificant. Hence, we reject the hypothesis $\mathrm{H} 3$ that investment expenditure by firms that hedge would respond more strongly to the investment opportunities (Q).

Following AM [26], and FHP [22], we include additional control variables viz. leverage, $\mathrm{Q}^{2}$ and firm size. Leverage is included as a proxy for financial distress. $\mathrm{Q}^{2}$ is included to control for the nonlinear adjustment cost function. Firm size is included to control for the size of the firm. Table-IV contains the regression results. The overall $\mathrm{R}^{2}$ is around $17.62 \%$. Based on the results reported in Table-IV, we find that the coefficient $\beta_{3}$ associated with hedging is positive but not statistically significant. Hence, we reject the hypothesis $\mathrm{H} 1$ that hedging increases investment expenditures. However, we find that the coefficient associated with hedging and cash flow interaction is equal to -0.05 and highly significant. This again supports the hypothesis $\mathrm{H} 2$ that hedging reduces the sensitivity of investments expenditures to cash flow. We also find that $\beta_{5}$, the coefficient associated with the interaction of $\mathrm{Q}$ and hedging, is equal to 0.011 and statistically significant. This fails to reject the hypothesis $\mathrm{H} 3$ that investment expenditure by firms that hedge would respond more strongly to the investment opportunities (Q). We find that the investment expenditure is negatively affected by lagged debt ratio. This is expected because higher the lagged debt ratio, lower the unused debt capacity, lower the ability of the firm to fund investment with debt, resulting in the negative relation between investments and leverage. This supports the underinvestment problem due to debt overhang identified by Myers and Majluf [14]. We also find that firm size measured as $\log$ (Total Assets) is positively correlated with investments. It is possible that larger and better known firms are financially less constrained which enable them to invest more in positive NPV projects. We find neither $\mathrm{Q}$ nor $\mathrm{Q}^{2}$ are significant.

\section{Robustness Checks}

Since both the base model and the extended model failed to reject the hypothesis that the financial hedging activity reduces the cash flow sensitivity of investment expenditures by firms, we now carry out robustness checks to see the possible reasons for this result. As mentioned earlier in the introduction if effective hedging reduces cash flow volatility, decreases the cost of distress, decreases a firm's expected tax liability, and increases debt capacity (i.e. enhances ability to generate funds from external capital markets), then the sensitivity of investment to internal cash flow should be less. Based on this argument, we examine two benefits of hedging viz. hedging increases debt capacity and hedging reduces the cash flow volatility.

\section{Effect of Hedging on leverage}

We follow Graham and Rogers [11] and use the following equation to study the effect of hedging on leverage

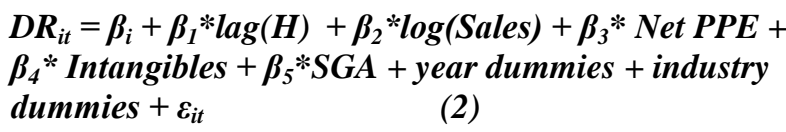

Here SGA is selling, general and administrative expense measured as percentage of net sales revenues. Log (Sales) is the natural logarithm of net sales revenues. Net PPE is measured as percentage of book value of total assets. $\operatorname{Lag}(\mathrm{H})$ is the lagged hedging variable scaled by book value of assets. Intangibles are book value of intangible assets as a percentage of book value of total assets. Debt ratio is measured as the ratio of book value of long term debt to the book value of total assets.

In this equation lag $(\mathrm{H})$ is the test variable and the other variables are used as controls. We included net PPE because the capital stock may be funded with debt capital. Also, sales, SG\&A and intangible assets can all affect leverage and accordingly added as controlled variables. We predict that $\beta_{1}$ should be positive. We also expect that $\beta_{3}$ and $\beta_{4}$ to be positive and $\beta_{5}$ to be negative.

The regression results of equation two above are reported in Table- $\mathrm{V}$. We find that $\beta_{1}$, the coefficient on lagged hedging, is equal to 0.10 and it is statistically significant. This indicates that hedging increases debt capacity and reproduces one of the results of Graham and Rogers [11]. We find that $\beta_{4}$, the coefficient on intangibles, is equal to 0.23 and it is statistically significant. The other variables are not found to be significant.

\section{B2. Effect of Hedging on cash flow variability}

Now we focus on the argument that hedging lowers cash flow variability. To examine this we use the following model:

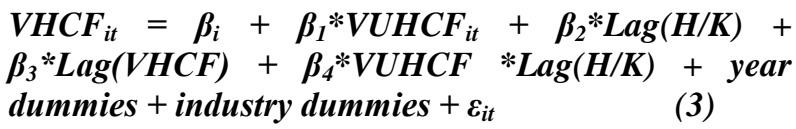


Here VHCF is variability of hedged cash flow. Following AM [26], we use net cash flow measured as net income plus depreciation and amortization as a measure of hedged cash flow. We follow Graham and Rogers [11] and measure the variability of hedged cash flow as absolute value of annual percentage change in hedged cash flow. VUHCF is variability of unhedged (before recognizing hedging effects) cash flow. As per AM [22], we measure the unhedged cash flow as NOPLAT $+\mathrm{DA}-\triangle \mathrm{WC}$. We define variability of unhedged cash flow as absolute value of annual percentage change in unhedged cash flow. Hedging variable is lagged as before. We interact VUHCF with $\operatorname{lag}(\mathrm{H} / \mathrm{K})$ to check if hedging reduces the dependence of variability of hedged cash flow on the variability of unhedged cash flow. Based on equation 3, we predict that both $\beta_{2}$ and $\beta_{4}$ as negative and $\beta_{1}$ and $\beta_{3}$ as positive.

The regression results of equation three above are reported in Table-VI. Based on the results reported in Table-VI, we find that the coefficient $\beta_{2}$ on lagged hedging is equal to -0.71 and it is highly significant. Similarly the coefficient $\beta_{4}$ on the interaction term is equal to -0.16 and also highly significant. These results confirm the theoretical predictions of Froot et al. that hedging reduces the cash flow variability. As predicted, we also find both the lag (VHCF) and VUHCF are positive and significant. These results are intuitive because both the lag(VHCF) and VUHCF should positively affect VHCF.

Debt ratio is measured as the ratio of book value of long term debt to the book value of total assets. Firm size is measured as a natural logarithm of book value of total assets. Q is measured as the ratio of market to book value of total assets. Investment (I) is measured as capital expenditure. $\mathrm{K}$ is measured as net PPE. Unhedged cash flow is measured as Net Operating Profit Less Adjusted Tax + Depreciation and Amortization - change in Working Capital (i.e., NOPLAT + DA $-\Delta \mathrm{WC})$.

Table-I: Explanatory Variables -Descriptive Statistics

\begin{tabular}{|l|c|c|c|c|c|c|}
\hline & I/K & Size & Lag(DR) & Q & CF/K & lag(H/K) \\
\hline Min. & 0.0950 & 7.8646 & 0.0155 & 0.9864 & 0.0719 & 0.0167 \\
\hline Max. & 0.7202 & 12.9877 & 0.4248 & 15.2520 & 2.3116 & 9.7928 \\
\hline Mean & 0.2471 & 9.8684 & 0.1939 & 2.9314 & 0.5549 & 1.1033 \\
\hline median & 0.2277 & 9.7824 & 0.1742 & 1.9175 & 0.5091 & 0.5742 \\
\hline Std. Dev. & 0.1064 & 1.2301 & 0.1187 & 2.3490 & 0.3869 & 1.5465 \\
\hline N & 106 & 133 & 105 & 133 & 102 & 93 \\
\hline
\end{tabular}

Debt ratio is measured as the ratio of book value of long term debt to the book value of total assets. Firm size is measured as a natural logarithm of book value of total assets. $\mathrm{Q}$ is measured as the ratio of market to book value of total assets. $\mathrm{K}$ is measured as net PPE. Unhedged cash flow is measured as NOPLAT+ DA - $\triangle \mathrm{WC}$. Investment is measured as capital expenditure. The p-values are reported below the correlation coefficients.

Table-II: Correlation among key variables

\begin{tabular}{|l|c|c|c|c|c|c|}
\hline & $\mathbf{I} / \mathbf{K}$ & $\mathbf{Q}$ & $\mathbf{C F} / \mathbf{K}$ & $\mathbf{L a g}(\mathbf{H} / \mathbf{K})$ & Size & Lag(DR) \\
\hline $\mathbf{I} / \mathbf{K}$ & 1 & & & & & \\
\hline & & & & & & \\
\hline $\mathbf{Q}$ & $0.1626^{*}$ & 1 & & & & \\
\hline & 0.0958 & & & & & \\
\hline & & & & & & \\
\hline $\mathbf{C F} / \mathbf{K}$ & $0.2780^{* * *}$ & $0.4226^{* * *}$ & 1 & & & \\
\hline & 0.0047 & 0 & & & & \\
\hline & & & & & & \\
\hline Lag(H/K) & 0.0134 & $-0.1814^{*}$ & $0.2813^{* * *}$ & 1 & & \\
\hline & 0.8989 & 0.0818 & 0.0076 & & & \\
\hline & & & & & & \\
\hline Firm Size & $0.4055^{* * *}$ & $-0.1632^{*}$ & $0.2276^{* *}$ & $0.2151^{* *}$ & 1 & \\
\hline & 0 & 0.0606 & 0.0214 & 0.0384 & & \\
\hline & & & & & & \\
\hline Lag(DR) & $-0.2397^{* *}$ & $-0.4476^{* * *}$ & $-0.1906^{*}$ & $0.3208^{* * *}$ & -0.1588 & 1 \\
\hline & 0.0138 & 0 & 0.0563 & 0.0018 & 0.1057 & \\
\hline
\end{tabular}

Debt ratio is measured as the ratio of book value of long term debt to the book value of total assets. Firm size is measured as a natural logarithm of book value of total assets. $\mathrm{Q}$ is measured as the ratio of market to book value of total assets. I is measured as capital expenditure. $\mathrm{K}$ is measured as net PPE. Unhedged cash flow is measured as NOPLAT + DA $\Delta$ WC. $\operatorname{Lag}(\mathrm{H} / \mathrm{K}) *(\mathrm{CF} / \mathrm{K})$ is the product of $\operatorname{lag}(\mathrm{H} / \mathrm{K})$ and $(\mathrm{CF} / \mathrm{K})$ and accounts for the interaction between the two terms. $\operatorname{Lag}(\mathrm{H} / \mathrm{K}) * \mathrm{Q}$ is the product of $\operatorname{lag}(\mathrm{H} / \mathrm{K})$ and 
$\mathrm{Q}$ and accounts for the interaction between the two terms. The year variables represent time dummies. The industry dummies are not reported as they are not jointly significant. The overall $\mathrm{R}^{2}$ is $2.34 \%$

$I_{i t} / K_{i t-1}=\beta_{i}+\beta_{1} * Q_{i t}+\beta_{2} *\left(C F_{i t} / K_{i t-1}\right)+\beta_{3} *\left(H_{i t-1} / K_{i t-1}\right)+\beta_{4}^{*}\left(C F_{i t} / K_{i t-1}\right) *\left(H_{i t-1} / K_{i t-1}\right)+\beta_{5} * Q_{i t} *\left(H_{i t-1} / K_{i t-1}\right)+y e a r d u m m i e s$ + industry dummies $+\varepsilon_{i t}$

Table-III: Basic Regression Results

\begin{tabular}{|l|c|c|c|c|}
\hline \multicolumn{1}{|c|}{$\mathbf{I} / \mathbf{K}$} & Coef. & Robust Std. Err. & t & P-value \\
\hline $\mathbf{Q}$ & $-0.0173^{* * *}$ & 0.0046 & -3.77 & 0.000 \\
\hline $\mathbf{C F} / \mathbf{K}$ & $0.0850^{* * *}$ & 0.0129 & 6.59 & 0.000 \\
\hline $\mathbf{l a g}(\mathbf{H} / \mathbf{K})$ & 0.0603 & 0.0435 & 1.39 & 0.171 \\
\hline $\mathbf{l a g}(\mathbf{H} / \mathbf{K})^{*}(\mathbf{C F} / \mathbf{K})$ & $-0.0269^{* * *}$ & 0.0061 & -4.42 & 0.000 \\
\hline $\mathbf{l a g}(\mathbf{H} / \mathbf{K}) * \mathbf{Q}$ & 0.0026 & 0.0057 & 0.45 & 0.654 \\
\hline _const. & 0.2292 & 0.0306 & 7.50 & 0.000 \\
\hline
\end{tabular}

Debt ratio is measured as the ratio of book value of long term debt to the book value of total assets. Firm size is measured as a natural logarithm of book value of total assets. $\mathrm{Q}$ is measured as the ratio of market to book value of total assets. I is measured as capital expenditure. $\mathrm{K}$ is measured as net PPE. Unhedged cash flow is measured as NOPLAT +DA -
$\Delta$ WC. $\operatorname{Lag}(\mathrm{H} / \mathrm{K})^{*}(\mathrm{CF} / \mathrm{K})$ is the product of $\operatorname{lag}(\mathrm{H} / \mathrm{K})$ and $(\mathrm{CF} / \mathrm{K})$ and accounts for the interaction between the two terms. $\operatorname{Lag}(\mathrm{H} / \mathrm{K})^{*} \mathrm{Q}$ is the product of $\operatorname{lag}(\mathrm{H} / \mathrm{K})$ and $\mathrm{Q}$ and accounts for the interaction between the two terms. The year variables represent time dummies. The industry dummies are not reported as they are not jointly significant. The overall $\mathrm{R}^{2}$ is $17.62 \%$.

$I_{i t} / K_{i t-1}=\beta_{i}+\beta_{1}^{*} Q_{i t}+\beta_{2}^{*}\left(C F_{i t} / K_{i t-1}\right)+\beta_{3}^{*}\left(H_{i t-1} / K_{i t-1}\right)+\beta_{4}^{*}\left(C F_{i t} / K_{i t-1}\right) *\left(H_{i t-1} / K_{i t-1}\right)+\beta_{5} * Q_{i t} *\left(H_{i t-1} / K_{i t-1}\right)+$ $\beta_{6} * \operatorname{Lag}(D R) *\left(H_{i t-1} / K_{i t-1}\right)+\beta_{7} * Q_{i t}{ }^{2}+\beta_{8} * \operatorname{lag}(D R)+\beta_{9} *$ Firm Size + year dummies + industry dummies $+\varepsilon_{i t}$

Table-IV: Regression with additional controls for size, leverage, $\mathbf{Q}^{2}$

\begin{tabular}{|l|c|c|c|c|}
\hline \multicolumn{1}{|c|}{ I/K } & Coef. & Robust Std. Err. & t & P-value \\
\hline $\mathbf{Q}$ & -0.0437 & 0.0293 & -1.49 & 0.142 \\
\hline $\mathbf{C F} / \mathbf{K}$ & $0.1761^{* * *}$ & 0.0656 & 2.68 & 0.010 \\
\hline $\mathbf{l a g}(\mathbf{H} / \mathbf{K})$ & -0.0093 & 0.0402 & -0.23 & 0.818 \\
\hline $\mathbf{l a g}(\mathbf{H} / \mathbf{K}) *(\mathbf{C F} / \mathbf{K})$ & $-0.0498^{* *}$ & 0.0193 & -2.59 & 0.013 \\
\hline $\mathbf{l a g}(\mathbf{H} / \mathbf{K}) * \mathbf{Q}$ & $0.0113^{* *}$ & 0.0050 & 2.26 & 0.028 \\
\hline $\mathbf{l a g}(\mathbf{H} / \mathbf{K}) * \mathbf{l a g}(\mathbf{D R})$ & 0.1578 & 0.1089 & 1.45 & 0.153 \\
\hline $\mathbf{Q}^{\mathbf{2}}$ & 0.0012 & 0.0014 & 0.85 & 0.402 \\
\hline $\mathbf{l a g}(\mathbf{D R})$ & $-0.5650^{* *}$ & 0.2176 & -2.60 & 0.012 \\
\hline Firm Size & $0.1521^{* *}$ & 0.0679 & 2.24 & 0.029 \\
\hline const. & $-1.1392^{*}$ & 0.6661 & -1.71 & 0.093 \\
\hline
\end{tabular}

Debt ratio is measured as the ratio of book value of long term debt to the book value of total assets. SGA is selling, general and administrative expense measured as percentage of net sales revenues. Log (Sales) is the natural logarithm of net sales revenues.
Net PPE is measured as percentage of book value of total assets. $\operatorname{Lag}(\mathrm{H})$ is the lagged hedging variable scaled by book value of assets. Intangibles are book value of intangible assets as a percentage of book value of total assets.

$D R_{i t}=\beta_{i}+\beta_{1} * \operatorname{lag}(H)+\beta_{2} * \log ($ Sales $)+\beta_{3} * N e t P P E+\beta_{4} *$ Intangibles $+\beta_{5} * S G A+y e a r$ dummies + industry dummies $+\varepsilon_{i t}$

Table-V: Effect of hedging on leverage

\begin{tabular}{|l|c|c|c|c|}
\hline \multicolumn{1}{|c|}{ DR } & Coef. & Robust Std. Err. & t & P-value \\
\hline H & $0.09276^{*}$ & 0.05062 & 1.830 & 0.073 \\
\hline Log(sales) & 0.00681 & 0.02891 & 0.240 & 0.815 \\
\hline Net PPE & 0.10727 & 0.15377 & 0.700 & 0.489 \\
\hline Intangibles & $0.22985^{*}$ & 0.11984 & 1.920 & 0.061 \\
\hline SG\&A & -0.08317 & 0.16812 & -0.490 & 0.623 \\
\hline const. & 0.06545 & 0.29348 & 0.220 & 0.824 \\
\hline
\end{tabular}

VHCF is hedged cash flow variability. Following AM [26], I use net cash flow measured as net income plus depreciation and amortization as a measure of hedged cash flow. I follow Graham and Rogers [11] and measure the variability of hedged cash flow as absolute value of annual percentage change in hedged cash flow. VHCF is unhedged (before recognizing hedging effects) cash flow variability. As per AM [32], 
I measure the unhedged cash flow as NOPLAT+ DA $\triangle \mathrm{WC}$. I define variability of unhedged cash flow as absolute value of annual percentage change in unhedged cash flow.

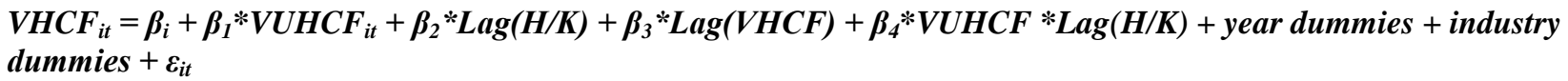

Table-VI: Effect of Hedging on Variabilty of Hedged Cash flow

\begin{tabular}{|l|c|c|c|c|}
\hline \multicolumn{1}{|c|}{ VHCF } & Coeff. & Robust Std. Err. & t & P-value \\
\hline VUHCF & $0.5713^{* *}$ & 0.2319 & 2.460 & 0.019 \\
\hline $\mathbf{L a g}(\mathbf{H} / \mathbf{K})$ & $-0.7127^{* *}$ & 0.3033 & -2.350 & 0.024 \\
\hline $\mathbf{L a g}(\mathbf{V H C F})$ & $0.5499^{* *}$ & 0.2018 & 2.720 & 0.010 \\
\hline VUHCF $* \mathbf{L a g}(\mathbf{H} / \mathbf{K})$ & $-0.1616^{* *}$ & 0.0673 & -2.400 & 0.022 \\
\hline const. & $0.5712^{* *}$ & 0.2336 & 2.440 & 0.020 \\
\hline
\end{tabular}

\section{CONCLUSIONS}

Using the broad based measure of total notional values of interest rate, and currency derivatives as a measure of financial hedging by non-financial S\&P 500 firms for a recent time period of 1996-2000, we find that financial hedging reduces the cash flow sensitivity of investment expenditures of sample firms. This is consistent with Allayannis and Mozumdar [20], and Deshmukh and Vogt [31]. This empirical evidence is also consistent with the theoretical prediction of Froot et al. [15]. This result holds even after controlling for several other variables like debt ratio, Tobin's Q, size etc.

In two separate robustness checks, we find that hedging increases debt capacity and also reduces the cash flow variability thus reducing the probability of financial distress. These findings establish the robustness of the main result of this paper that financial hedging reduces the cash flow sensitivity of investment expenditures by firms and also reproduces the earlier research results of Graham and Rogers [11]. We also find that investments are significantly negatively related with leverage supporting the underinvestment problem of Myers and Majluf [14]. Finally, we find that investment expenditures are positively correlated to internal cash flow, as predicted by FHP [22], and firm size.

We plan to extend this paper by using a large sample of S\&P 500 firms and using net notional values, fair values as alternative measures for financial hedging and also include commodity and equity hedging. Another, important extension for a future study is to directly examine the effect of hedging on cost of debt $(\mathrm{Kd})$, cost of equity $(\mathrm{Ke})$ and WACC.

\section{REFERENCES}

1. Modigliani, F., Miller, M. (1958). The Cost of Capital, Corporation Finance and the Theory of Investment, American Economic Review 48, 267297.

2. Stulz, R., (1984), Optimal hedging policies, Journal of Financial and Quantitative Analysis, 19, 127-140, June
3. Haushalter, David, (2000), Financing policy, basis risk, and corporate hedging: Evidence from oil and gas producers, Journal of Finance, 55, 107-152.

4. Geczy, Christopher, Bernadette Minton, and Catherine Schrand, (1997), Why firms use currency derivatives, Journal of Finance, 52, 1323-1354.

5. DeMarzo, Peter M, and Darrell Duffie. (1991). Corporate financial hedging with proprietary information, Journal of Economic Theory, 53, 261286

6. Bessembinder, Hendrik. (1991). "Forward Contracts and Firm Value: Investment Incentive and Contracting Effects" Journal of Financial and Quantitative Analysis. 26, 519-32

7. Hubbard, R. Glenn. (1998). Capital-market imperfections and investment, Journal of Economic Literature, 36, 193-225.

8. Breeden, D. and Viswanathan, S. (1998). Why do firms hedge? An asymmetric information model. Working paper, Fuqua School of Business, Duke University, Durham, NC.

9. Smith, C. W., \& Stulz, R. M. (1985). The determinants of firms' hedging policies. Journal of financial and quantitative analysis, 20(4), 391-405.

10. Purnanandam, A. (2008). Financial distress and corporate risk management: Theory and evidence. Journal of Financial Economics, 87(3), 706-739.

11. Graham, J. R., \& Rogers, D. A. (2002). Do firms hedge in response to tax incentives? The Journal of Finance, LVII: 815-839.

12. Mian, S. L., (1996). Evidence on Corporate Hedging Policies, Journal of Financial and Quantitative Analysis, 31, 419-439.

13. Tuffano, Peter. (1996). Who Manages Risk? An Empirical Examination of Risk Management Practices in the Gold Mining Industry, the Journal of Finance 51, 1097-1137.

14. Myers, Stewart C., and Nicholas S. Majluf. (1984). Corporate financing and investment decisions when firms have information that investors do not have, Journal of Financial Economics, 13, 187-221.

15. Froot, K. A., Scharfstein, D. S., \& Stein, J. C. (1993). Risk management: Coordinating corporate investment and financing policies. the Journal of Finance, 48(5), 1629-1658. 
16. Gay, Gerald, D., \& Jouhan Nam. (1998). The underinvestment problem and corporate derivatives use, Financial Management, 27, 53-69

17. Ross, Michael, P. (1997). Corporate hedging: What, why and how?, working paper, University of California, Berkeley

18. Leland, H. E. (1998). Agency costs, risk management and capital structure. Journal of Finance, 53, 1213 - 1243.

19. Carter, David, A., Rogers, Daniel, A., \& Simkins, Betty J. (2006). "Hedging and Value in the U.S. Airline Industry", Journal of Applied Corporate Finance, 18, 4, 21-33

20. Allayannis, G., \& Ofek, E. (2001). Exchange rate exposure, hedging, and the use of foreign currency derivatives. Journal of international money and finance, 20(2), 273-296.

21. Lin, C. M., \& Smith, S. D. (2007). Hedging, financing and investment decisions: A simultaneous equations framework. Financial Review, 42(2), 191-209.

22. Steven, F., Hubbard, R. G., \& Petersen, B. (1988). Financing constraints and corporate investment. Brooking Papers on Economic Activity, 1, 141-195.

23. Kaplan, S. N., \& Zingales, L. (1997). Do investment-cash flow sensitivities provide useful measures of financing constraints?. The quarterly journal of economics, 112(1), 169-215.

24. Moyen, N. (2004). Investment-cash flow sensitivities: Constrained versus unconstrained firms. The Journal of finance, 59(5), 2061-2092.

25. Allayannis, G., \& Weston, J. P. (2001). The use of foreign currency derivatives and firm market value. The review of financial studies, 14(1), 243276.

26. Allayannis, G., \& Mozumdar, A. (2000, June). Cash flow, investment, and hedging. In AFA 2001 New Orleans Meetings.

27. Bodnar, G. M., Hayt, G. S., \& Marston, R. C. (1998). 1998 Wharton survey of financial risk management by US non-financial firms. Financial management, 70-91.

28. Chung, S. Y. (2004). Do Financial Analysts Value Corporate Hedging Strategies?: A Case of Precious Metal Mining Firms. A Case of Precious Metal Mining Firms (December 2003). EFMA.

29. Harvey, C. R., Lins, K. V., \& Roper, A. H. (2004). The effect of capital structure when expected agency costs are extreme. Journal of Financial Economics, 74(1), 3-30.

30. Adam, T., \& Goyal, V. K. (2008). The investment opportunity set and its proxy variables. Journal of Financial Research, 31(1), 41-63.

31. Deshmukh, S., \& Vogt, S. C. (2005). Investment, cash flow, and corporate hedging. Journal of Corporate Finance, 11(4), 628-644.

32. Wooldridge, J. M. (2010). Econometric analysis of cross section and panel data. MIT press.

33. Hoshi, T., Kashyap, A., \& Scharfstein, D. (1991). Corporate structure, liquidity, and investment: Evidence from Japanese industrial groups. The Quarterly Journal of Economics, 106(1), 33-60.

34. Petersen, M. A. (2009). Estimating standard errors in finance panel data sets: Comparing approaches. The Review of Financial Studies, 22(1), 435-480. 